\title{
Comparative morphometric study of adipose tissue in ovariectomized mice of different ages
}

\author{
Ivanishchev V. ${ }^{1}$, Ustymenko A. ${ }^{1,2}$, Kyryk V. ${ }^{1,2}$, Butenko G. ${ }^{1,2}$ \\ ${ }^{1}$ D. F. Chebotarev State Institute of Gerontology of the National Academy of Medical Sciences of Ukraine, Kyiv, Ukraine \\ ${ }^{2}$ State Institute of Genetic and Regenerative Medicine of the National Academy of Medical Sciences of Ukraine, Kyiv, Ukraine \\ e-mail: meddoc@i.ua
}

\section{ABSTRACT}

It is known that estrogen deficiency leads to the dysfunction of many organs and systems, including adipose tissue. Therefore, the study of morphological changes in the components of adipose tissue during estrogen deficiency will expand our understanding of both its dysfunction and possible ways to correct it.

THE PURPOSE of the study is to conduct a comparative analysis of morphometric parameters of subcutaneous adipose tissue in ovariectomized mice of different ages.

\begin{abstract}
MATERIALS AND METHODS. Subcutaneous adipose tissue samples from young (2 months) and old (14 months) mice were studied two months after ovariectomy in comparison with the samples from sham-operated animals of the same age. The number of adipocytes and capillaries per $1 \mathrm{~mm}^{2}$ of the area and the average area of adipocyte were determined on histological slices of adipose tissue.
\end{abstract}

RESULTS AND DISCUSSION. It was shown that along with a significant decrease in the number of adipocytes per $1 \mathrm{~mm}^{2}$ of the area in young ovariectomized mice, a significant increase in the average area of adipocytes was observed compared with the control group of animals of the same age. In old ovariectomized animals at a slight decrease in the number of adipocytes, there was also a probable increase in their average area compared with the control group of the same age.

CONCLUSION. The morphological properties of subcutaneous adipose tissue change significantly in the conditions of artificially induced estrogen deficiency during ovariectomy in mice.

KEY WORDS: subcutaneous adipose tissue; adipocyte; ovariectomy; morphometry

Adipose tissue is a type of connective tissue that performs a number of functions, including the deposition and production of reproductive hormones [5]. From the puberty to the menopause, the ovaries are the main organ that produces female sex hormones - estrogens, progestagens, and androgens [4]. Adipose tissue, placenta and other peripheral tissues also produce estrogen in small amounts. Estrogens are the main hormones of the females [6]. Due to the binding with specific receptors, estrogens have an effect on the reproductive system; regulate the functions of the mammary gland, skin, hair growth and metabolism [7]. Physiological decrease in hormone production by the ovaries (menopause) or surgical menopause when both ovaries are removed (oophorectomy) leads to the development of estrogen deficiency of varying severity: from mild to severe functional disorders in women $[4,6]$.

Rocca et al. found the relationship between pre-menopausal bilateral oophorectomy and the development of multimorbidity, namely the presence of 18 most common chronic diseases in various combinations. Ovariectomy and following multimorbidity may be the factors of the ac- celerated aging [24]. Thus, according to Levine et al., early loss of ovarian function leads to increased DNA methylation, which is a well-known biological marker of accelerated aging [20].

The development of estrogen deficiency is often accompanied by weight gain, which occurs mainly due to adipose tissue. Adipocytes increase in size and become hypertrophied $[8,16]$. Weight gain in women begins in the perimenopause and averages $5.5 \mathrm{~kg}$ over 8 years [2]. In order to compensate for the estrogen deficiency, the body enhances the production of estrogen by other tissues. Thus, in postmenopausal women, adipose tissue is a source of almost all circulating estrogens [3]. Similar changes are observed in animals. According to Stubbins et al., ovariectomized $(\mathrm{OVx})$ mice had a higher susceptibility to obesity and larger adipocytes compared to intact female mice [23]. Gomes-Gatto et al. showed that ovariectomy in rats also led to weight gain and adipocyte hypertrophy [14].

Adipose tissue is a source of multipotent mesenchymal stromal cells (MMSCs), which have shown efficacy in the treatment of various diseases 
[9]. Obesity causes quantitative and qualitative changes in various types of cells in adipose tissue, including stem cells. These changes in adipose tissue functions and properties impair both adipose tissue remodeling and function, leading to low-grade systemic inflammation, progressive insulin resistance, and other metabolic disorders [25]. According to OlivaOlivera et al., in patients with metabolic disorders there was a decrease in expression levels of adipogenic genes, decrease in proliferation rate and clonogenic potential of adipose tissue stem cells; and their susceptibility to apoptosis differed in patients without and with metabolic syndrome [22]. Adipose-derived MMSCs in obese patients produce higher levels of proinflammatory cytokines compared to healthy people [13]. Research by Kaijing Song et al. demonstrates that adipose tissue MMSCs in combination with estrogen affect regulatory T-cells in vitro in patients with premature ovarian insufficiency [26]. Studying the physiological and biological properties of adipose-derived MMSCs in healthy people and during diseases can help develop more effective means of using these cells in regenerative medicine, as well as provide new therapeutic algorithms for the treatment of various diseases, including obesity and diabetes.

\section{MATERIALS AND METHODS}

The experimental work was performed on female $\mathrm{CBA} / \mathrm{Ca}$ mice: young at the age of 2 months (body weight $22.5 \pm 1.1 \mathrm{~g}$ ) and old at the age of 14 months (body weight $24.6 \pm 0.6 \mathrm{~g}$ ) from the vivarium of the D. F. Chebotarev State Institute of Gerontology of the National Academy of Medical Sciences of Ukraine. The mice were maintained under standard housing conditions of 12:12 hours of light/dark cycle and a standard diet and water ad libitum. Animals were divided into 4 groups: young ovarioectomized or control, and old ovarioectomized or control; 4 mice were examined in each group.

Animals were anesthetized by intraperitoneal administration of $2.5 \%$ solution of 2,2,2-tribromethanol (Sigma, USA) at a dose of $400 \mathrm{mg} / \mathrm{kg}$ and bilateral ovariectomy was performed in aseptic conditions. Animals of the same age underwent a sham surgery as a control: incision of the abdominal cavity and isolation of the ovaries without their resection. Wounds were sutured in layers; the animals were kept under a heat lamp until the recovery from anesthesia. 60 days after ovariectomy, the animals were euthanized by cervical dislocation under anesthesia with $2.5 \%$ solution of 2,2,2-tribromethanol (400 mg/kg). After euthanasia, subcutaneous fat was isolated from mice under sterile conditions for morphological examination

The object of the morphological study was the fragments of subcutaneous adipose tissue isolated from the abdominal wall. Tissue samples were fixed in $10 \%$ neutral formalin solution for 24 hours. Formalin-fixed tissues were dehydrated by immersion through ethanol, gradually increasing the concentration from $70 \%$ to $96 \%$, and then embedded into paraffin blocks (Leica Biosystems Richmond, Inc., USA).

Histological sections 5-6 $\mu \mathrm{m}$ thick were prepared from the blocks using a rotary microtome HN 325 (Thermo Scientific, USA). Histological processing of the experimental samples was performed according to the standard procedure [1]. Hematoxylin-eosin staining was used to study the characteristics of adipose tissue. The sections were analyzed using a microscope BX-41 (Olympus, Japan), digital photography was performed using a camera SP-500 UZ (Olympus, Japan), followed by image processing using DP-soft ver. 3.1 (Olympus, Japan).

Morphometric analysis was performed using Image $\mathrm{J}$ software (Wayne Rasband, NIH, USA). The number of adipocytes and the number of capillaries per $1 \mathrm{~mm}^{2}$ of the cross-sectional area, as well as the average area of adipocytes $\left(\mu \mathrm{m}^{2}\right)$ were determined.

Statistica v 7.0 software (Statsoft Inc., USA) was used for statistical analysis of the data. The mean values and standard errors in different groups, as well as interquartile range $\left(25^{\text {th }}\right.$ and $75^{\text {th }}$ percentiles) were calculated. The results are presented as the mean and standard error (Mean \pm SEM). The Shapiro-Wilk test was used to test the normality of the variables distribution. The comparison of rankings between groups was performed using the nonparametric Mann-Whitney $U$ test. The differences were considered statistically significant at $p \leq 0.05$.

\section{RESULTS AND DISCUSSION}

Subcutaneous adipose tissue consisting of parenchymal and stromal components was determined in the study of histological sections in the experimental groups. The parenchymal component of adipose tissue is represented by adipocytes. The shape of adipocytes was different round, oval, and polygonal. When staining sections with hematoxylin and eosin, the cytoplasm of adipocytes was optically empty with flattened nuclei displaced peripherally.

It should be noted that both single brown adipocytes and their clusters were observed in animals' white adipose tissue (Fig. 1). Such cells were smaller and polygonal in shape compared with white adipocytes. They had round nuclei located in the center as well. According to the literature data, brown adipocytes contain many small lipid droplets which diffuse in the cytoplasm, as well as mitochondria. Therefore, their protoplasm is brightly stained with basic dyes and looks optically filled compared to white adipocytes [5].

The number of adipocytes varied in the experimental groups (Fig. 2). Thus, in young ovariectomized mice the number of adipocytes per crosssectional area $\left(626.0 \pm 74.1 \mathrm{cell} / \mathrm{s} / \mathrm{mm}^{2}\right)$ significantly decreased $(p<0.05)$ according to the control group without ovariectomy $\left(915.0 \pm 72.3 \mathrm{cell} / \mathrm{s} / \mathrm{mm}^{2}\right)$ (Fig. 3). Statistically significant changes in the number of adipocytes in old ovariectomized and control mice were not detected, but there was a slight tendency to decrease the number of adipocytes in old ovariectomized mice $\left(757.0 \pm 165.3\right.$ cells $\left./ \mathrm{mm}^{2}\right)$ compared with the control group (812.0 \pm 109.1 cells $/ \mathrm{mm}^{2}$ ) (Fig. 4)

The cross-sectional area of adipocytes also differed in groups (Fig. 5). In young ovariectomized mice there was a significant increase in the average adipocyte cross-sectional area, which was $1112.0 \pm 51.0 \mu \mathrm{m}^{2}$ while this parameter in the control group was $794.0 \pm 37.2 \mu \mathrm{m}^{2}(p<0.001)$. Similarly, the mean adipocyte cross-sectional area in the group of old ovariectomized mice $\left(1294.0 \pm 58.7 \mu \mathrm{m}^{2}\right)$ significant increased $(p<0.001)$ comparing with the control group of the same age $\left(1061.0 \pm 56.1 \mu \mathrm{m}^{2}\right)$.

It is known that estrogens protect the female body from obesity [15]. Obesity is characterized by an increase in the volume and mass of adipose tissue due to hyperplasia (increase in the number of adipocytes) and

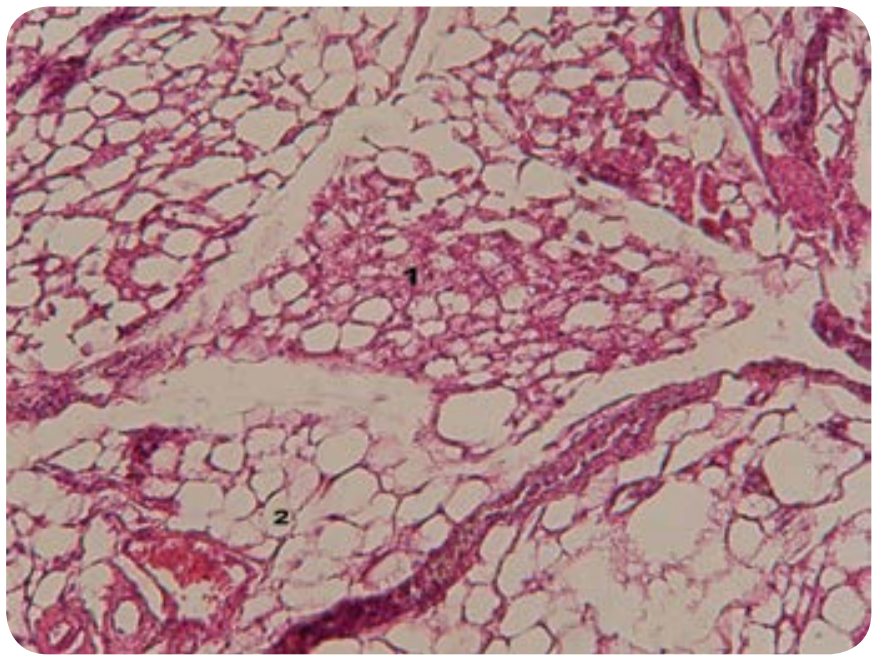

Fig. 1. Micrographs of the histological section of subcutaneous adipose tissue of an old mouse aged 16 months (control group). Brown (1) and white (2) adipocytes are marked. Light microscopy, hematoxylin and eosin staining; ob. x20, oc. x10 


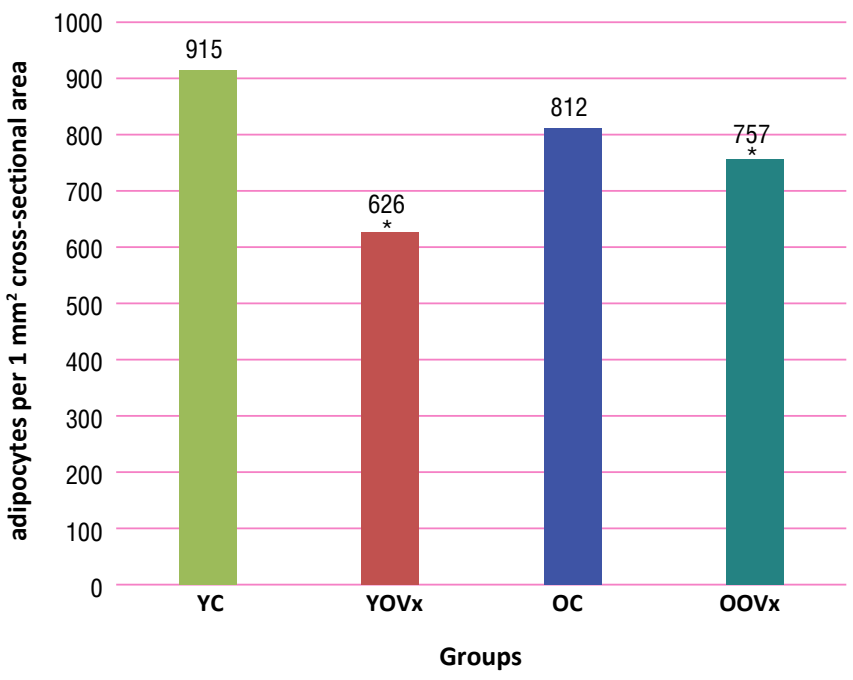

$\boldsymbol{A}$

Fig. 2. The average number of adipocytes per $1 \mathrm{~mm}^{2}$ cross-sectional area of adipose tissue in animals of experimental groups.

Notes: $Y C$ - young animals, control group, YOVX - young ovariectomized, OC - old, control group, OOVX - old ovariectomized. ${ }^{*}-p<0.05$ compared with the control group of the same age.

hypertrophy (increase in the size of adipocytes) [19]. Simulation of estrogen deficiency by surgical removal of the ovaries (ovariectomy) increases the susceptibility of female mice to obesity [21].

Our studies indicate that ovariectomy has led to an increase in the size (hypertrophy) of adipocytes of subcutaneous adipose tissue in young and old ovariectomized mice relatively to control groups, resulting in a decrease in the number of adipocytes per cross-sectional area. This is confirmed by the results of other researchers [23]. The increase of adipocytes size is likely to cause the increase of animal body weight. Thus, during the experiment, the weight of young ovariectomized animals $(25.0 \pm 1.6 \mathrm{~g})$ significantly increased $(p<0.001)$ compared to the weight of the control group $(22.5 \pm 1.2 \mathrm{~g})$. This is also confirmed by the data of other researchers. Hong et al. proved that female mice gained weight after ovariectomy [15]. In addition, Gomes-Gatto et al. showed that ovariectomy in rats is also the cause of weight gain and adipocyte hypertrophy [14]. It is also known that ovariectomy in experimental animals (mice, rats) causes a decrease in the level of circulating estradiol in the blood, a tendency to

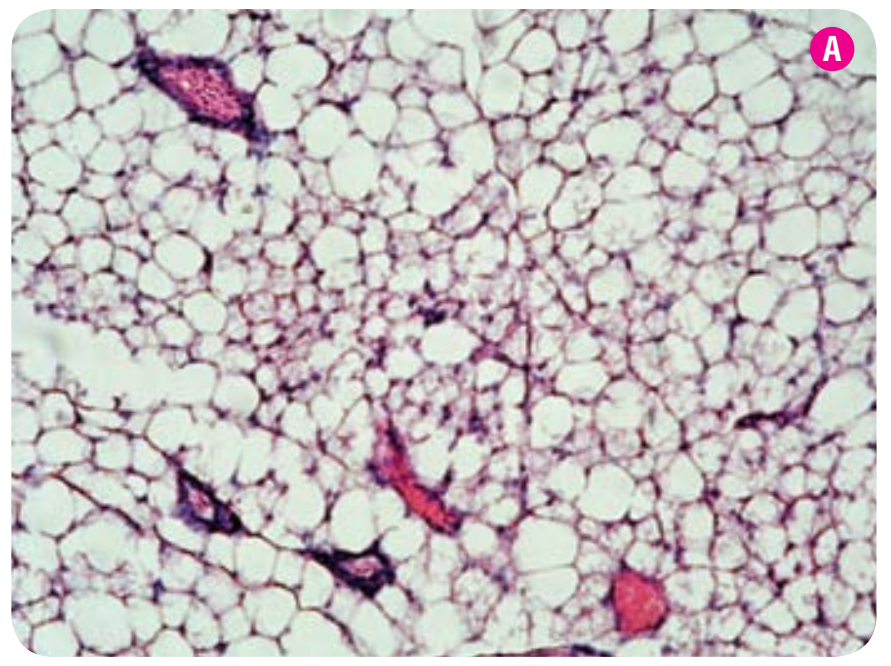

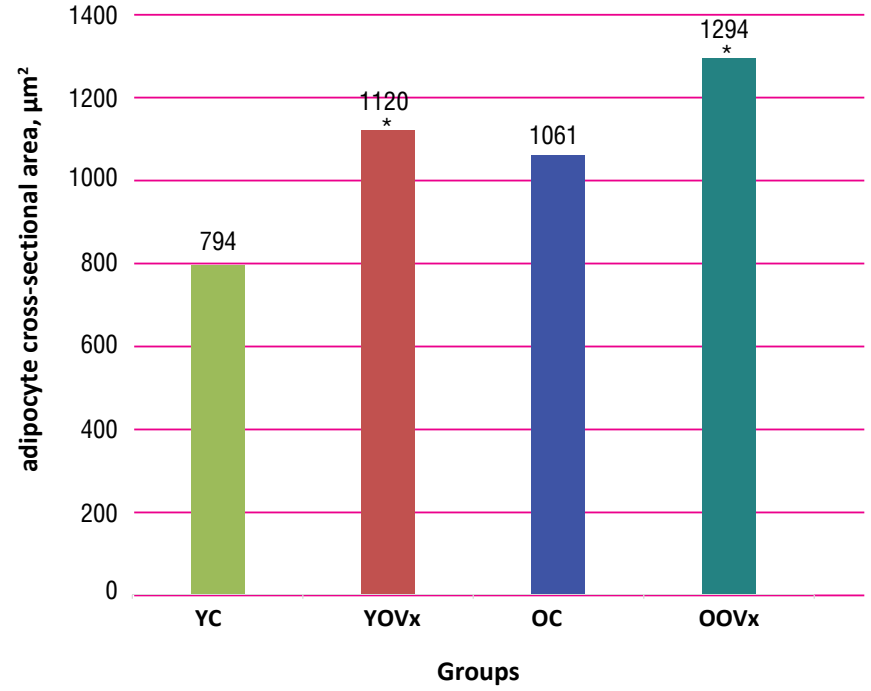

$\boldsymbol{A}$

Fig. 5. The average adipocyte cross-sectional area of subcutaneous adipose tissue sections in mice of experimental groups, $\mu \mathrm{m}^{2}$

Notes: YC - young animals, control group, YOVX - young ovariectomized, OC - old, control group, 00Vx - old ovariectomized. ${ }^{*}-p<0,001$ compared with the control group of the same age.

develop insulin resistance and various metabolic disorders that can affect body weight [12].

Adipose tissue is highly vascularized and each adipocyte is surrounded by one or more capillaries, which provides close contacts between cells and blood vessels [11]. Histological analysis of sections showed that the stromal component of the subcutaneous adipose tissue of female mice is represented by vessels of different diameters located in the layers of loose connective tissue. Some of them contained blood cells (Fig. 6). Morphometric analysis of blood vessels showed no significant changes in their number. However, there was a tendency to the increase of the number of capillaries per cross-sectional area in the group of young ovariectomized animals (14.74 \pm 5.7 per $\left.1 \mathrm{~mm}^{2}\right)$, compared with the control group of young mice $\left(12.38 \pm 1.9\right.$ per $\left.1 \mathrm{~mm}^{2}\right)$, as well as an increase in the number of vessels in old ovariectomized animals $\left(13.01 \pm 3.0\right.$ per $\left.1 \mathrm{~mm}^{2}\right)$, compared with the old control group (12.02 \pm 2.8 per $\left.1 \mathrm{~mm}^{2}\right)$ (Fig. 7).

Estrogen plays a significant role in the angiogenesis in various tissues, including adipose tissue [27]. In particular, Fatima et al. showed

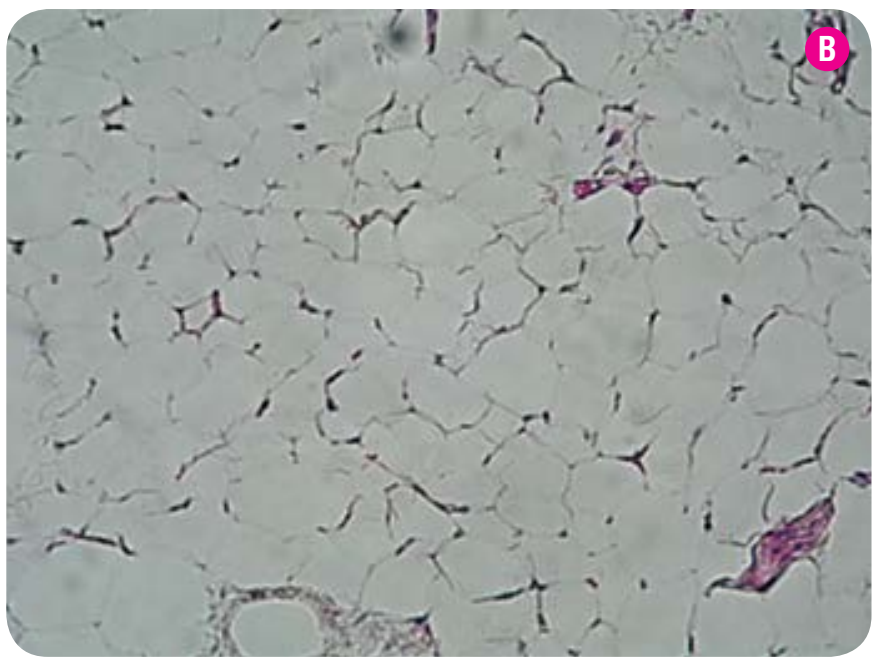

Fig. 3. Micrographs of the histological sections of subcutaneous adipose tissue of young mice aged 4 months: A - control group, B - ovariectomized. Light microscopy, hematoxylin and eosin staining; ob. x20, oc. x10. 

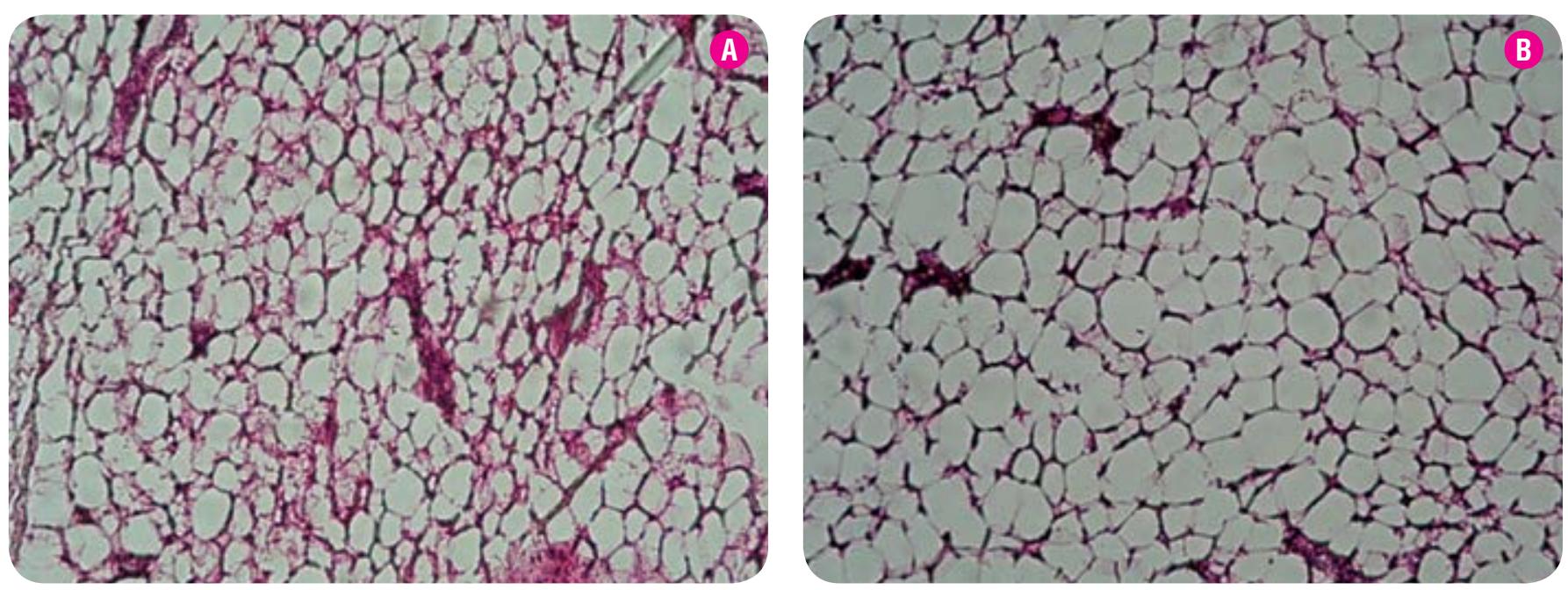

Fig. 4. Micrographs of the histological sections of subcutaneous adipose tissue of old mice aged 16 months: A - control group, B - ovariectomized. Light microscopy, hematoxylin and eosin staining; ob. x20, oc. x10.

that estrogen regulates the expression of vascular endothelial growth factor (VEGF) through binding to estrogen receptors (ESR1) in the adipose tissue of female mice. Hypertrophied adipocytes of visceral and subcutaneous adipose tissue decrease VEGF expression, reducing tissue vascularization, respectively [18]. According to Gomes-Gatto et al., ovariectomy also reduced the density of blood vessels in the adipose tissue of ovariectomized rats [14]. In our study, we did not obtain quantitative changes in capillaries per cross-sectional area in ovariectomized mice of both age groups, so this issue needs further study.

In general, the ovariectomy model is used to study the effects of hormone deficiency, namely estrogen, on the female body [14]. Estrogen-deficient conditions caused by ovariectomy lead to severe diseases (cardiovascular, cancer, osteoporosis), metabolic syndrome, accelerated biological aging [20, 24]. Hormonal changes in women also change the external condition of the skin, its structure and functions, in particular, xerosis, wrinkles, impaired wound healing and atrophy [10]. Skin aging under estrogen deficiency also has a negative impact on women's mental and emotional health.

Hormone replacement therapy has been associated to some beneficial effects, such as weight loss and reduced inflammation in adipose tis-

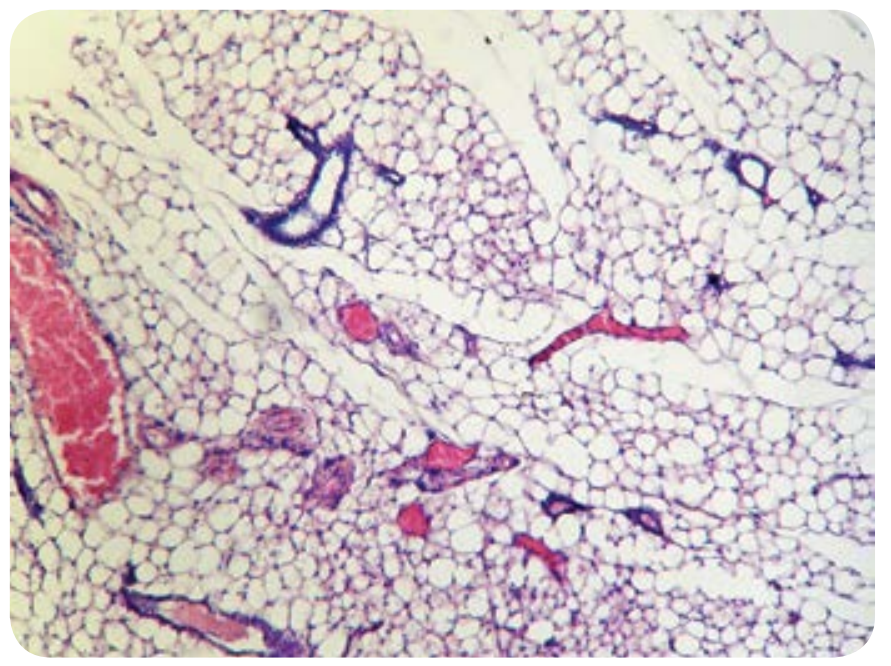

Fig. 6. Micrograph of histological section of subcutaneous adipose tissue in a young mouse aged 4 months, control group. Light microscopy, hematoxylin and eosin staining; ob. x20, oc. x10. sue. However, the use of estrogen has some limitations, mainly due to the presence of contraindications in some patients. In addition, long-term use of such therapy can cause hormone-dependent cancer [28]. Therefore, the study of estrogen deficiency, as well as the effects of low doses of estrogen during menopause and postmenopause in women to develop strategies for both systemic treatment and topical drugs, is extremely important for clinical and aesthetic medicine [17]. At the same time, new experimental data on morphological changes in adipose tissue under estrogen deficiency may expand our understanding of adipose tissue dysfunction and possible ways to correct it in this pathology.

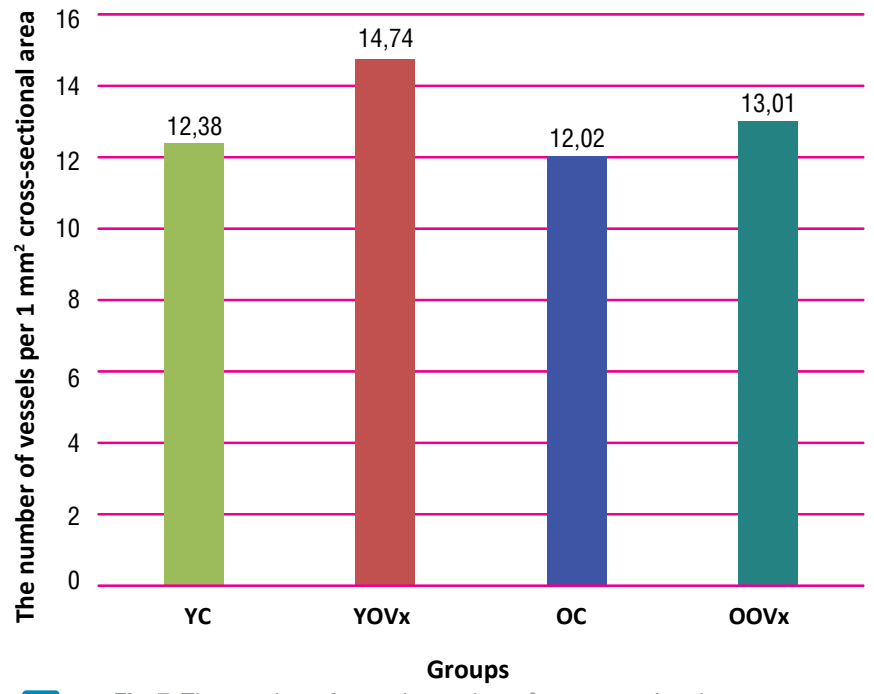

Fig. 7. The number of vessels per $1 \mathrm{~mm}^{2}$ cross-sectional area of adipose tissue in mice of experimental groups.

Notes: YC - young animals, control group, YOVX - young ovariectomized, OC-old, control group, OOVx-old ovariectomized. 


\section{CONCLUSION}

Ovariectomy is accompanied by significant morphological changes in the subcutaneous adipose tissue of female CBA/Ca mice. A significant increase in the average cross-sectional area of adipocytes was found in both the group of young and old ovariectomized mice compared with control animals of the same age.

A significant decrease in the number of adipocytes per cross-sectional area was found in both young and old ovariectomized mice compared with control groups of the same age.

\section{REFERENCES}

1. Volkova OV, Yeletsky YuK. Osnovy gistologii s gistologicheskoy tekhnikoy. [Basics of Histology with Histological Technique]. Moskva: Meditsina, 1982.304 p. [In Russian]

2. Grigoryan OR, Andreeva EN. Sostoyanie uglevodnogo obmena u zhenshchin v period menopauzy [The state of carbohydrate metabolism in women during menopause]. Reproduktivnoe zdorov'e i sakharnyy diabet - Reproductive health and diabetes. 2009; 4:15-20. [In Russian]

3. Dedov II. Zhirovaya tkan' kak endokrinnyy organ [Adipose tissue as an endocrine organ]. Ozhirenie i metabolizm - Obesity and metabolism. 2006; 1:6-13. [In Russian]

4. Kishkun AA. Biologicheskiy vozrast i starenie: vozmozhnosti opredeleniya i puti korrektsii. Ruk-vo dlya vrachey. [Biological age and aging: possibilities of definition and ways of correction. Manual for doctors]. Moskva: GEOTAR-Media, 2008. 973 p. [In Russian]

5. Myadelets OD. Belaya i buraya zhirovye tkani: vzaimodeystvie so skeletnoy myshechnoy tkan'yu [White and brown adipose tissue: interactions with skeletal muscle tissue]. Vestnik VMGU - VMGU Bulletin. 2014; 13(5):32-44. [In Russian]

6. Ovsyannikova TV, Kulikov IA. Printsipy naznacheniya monoterapii estrogenami. [Principles of prescribing estrogen monotherapy]. Meditsinskiy sovet - Medical advice. 2015; 9:66-70. [In Russian]

7. Serov VN, Prilepskaya VN, Ovsyannikova TV. Ginekologicheskaya endokrinologiya [Gynecological endocrinology]. Moskva: MEDpress, 2015.528 p. [In Russian]

8. Sulaeva ON, Belemets NI. Polovye osobennosti regulyatsii zhirovoy tkani [Sexual features of adipose tissue regulation]. Klinicheskaya endokrinologiya i endokrinnaya khirurgiya - Clinical endocrinology and endocrine surgery. 2017; 4(60):11-20. [In Russian]

9. Startseva OI, Melnikov DV, Zakharenko AS, Kirillova KA, Ivanov SI, Pischikova ED, et al. Mesenchymal stem cells of adipose tissue: a modern view, the relevance and prospects of application in plastic surgery. Issled. prakt. med. Research'n Practical Medicine Journal. 2016; 3(3):68-75. D0I: 10.17709/2409-2231-2016-33-7.

10. Rzepeckiet AK, Murase JE, Juran R, Fabi S, McLellan BN. Estrogen-deficient skin: The role of topical therapy Int J Womens Dermatol. 2019; 5(2):85-90. D0I: 10.1016/j.jijwd.2019.01.001.

11. Cao Y. Angiogenesis and vascular function sinmodulation of obesity, adipose metabolism, and insulinsensitivity. Cell Metab. 2013; 18(4):478-89.

12. Campbell SE, Febbraio MA. Effect of the ovarian hormones on GLUT4 expression and contraction-stimulated glucose uptake. Am J Physiol Endocrinol Metab. 2002; 282:1139-1146.

13. Serena C, Keiran N, Ceperuelo-Mallafre V, Ejarque M, Fradera R, Roche K, et al. Obesity and Type 2 Diabetes alters the immune properties of human Adipose Derived Stem Cell. Stem Cell. 2016; 34(10):2559-2573. DOI: 10.1002/stem.2429.

14. Gomes-Gatto CV, Duarte FO, Stotzer US, Rodrigues MF, Perez SE, Selistre de Araujo HS. Estrogen deficiency in ovariectomized rats: can resistance training reestablish angiogenesis in visceral adipose tissue?. Clinics. 2016; 71(9):528-536.

15. Hong J, Stubbins RE, Smith RR, Harvey AE, Núñez NP. Differential susceptibility to obesity between male, female and ovariectomized female mice. 2009; 8(11). DOI: $10.1186 / 1475-2891-8-11$

16. Jo J, Gavrilova 0, Pack S, et. al. Hypertrophy and/or Hyperplasia: Dynamics of Adipose Tissue Growth. PLoS Comput Biol. 2009; 5:1000324.

17. Leeners B, Geary N, Tobler PN, Asarian L. Ovarian hormones and obesity. Hum Reprod Update. 2017; 23(3):300-321.

18. Fatima LA, Campello RS, Santosetal R. Estrogenreceptor 1 (ESR1) regulates VEGFA in adipose tissue. article. Sci Rep. 2017; 7(1). DOI: 10.1038/s41598-01716686-7.

19. Lee H, Choi J, ShikShin S, Yoon M. (Effects of Korean red ginseng (Panaxginseng) on obesity and adipose inflammation in ovariectomized mice. J Ethnopharmacol. 2016; 178:229-237.

20. Levine ME, Lu AT, Chen BH, Hernandez DG, Singleton AB, Ferrucci L, at al. Menopause accelerates biological aging. Proc Natl Acad Sci U S A. 2016; 113(33):9327-9332.

21. Nunez NP, Perkins SN, Smith NC, Berrigan D, Berendes DM, Varticovski L, et al. Obesity accelerates mouse mammary tumor growth in the absence of ovarian hormones. Nutr Cancer. 2008; 60(4):534-41.

22. Oliva-Olivera W, Coin-Araguez L, Lhamyani S, Clemente-Postigo M, Torres JA, Bernal-Lopez MR, et al. Adipogenic impairment of adiposetissue-derived mesenchymal stem cells in subjects with metabolic syndrome:possible protective role of FGF2. J Clin Endocrinol Metab. 2017; 102:478-487.

23. Stubbins RE, Najjar K, Holcomb VB, Hong J, Núñez NP. Estrogen alters adipocyte biology and protects female mice from adipocyte inflammation and insulinresistance Diabetes Obes Metab. 2012; 14(1):58-66.

24. Rocca WA, Gazzuola-Rocca L, Smith CY, et al. Accelerated Accumulation of Multimorbidity After Bilateral Oophorectomy: A Population-Based Cohort Study. Mayo Clin Proc. 2016; 91(11):1577-1589.

25. Shin S, El-Sabbagh AS, Lukas BE, Tanneberger SJ, Jiang, Y. Adipose stem cells in obesity: challenges and opportunities. Bioscience reports. 2020; 40(6). URL: https://doi.org/10.1042/BSR20194076.

26. Song K, Cai H, Zhang D, et al. Effects of human adipose-derived mesenchymal stem cells combined with estrogen on regulatory $\mathrm{T}$ cells in patients with premature ovarian insufficiency. Int Immunopharmacol. 2018; 55:257-262. 
27. Zhang Y, Hua F, Ding K, Chen H, Xu Ch, Ding W. Angiogenesis Changes in Ovariectomized Rats with Osteoporosis Treated with Estrogen Replacement Therapy. Bio Res Int. 2019. DOI: 10.1155/2019/1283717.

28. Zhang SM, Manson JE, Rexrode KM, Cook NR, Buring JE, Lee IM. Use of oral conjugated estrogen alone and risk of breast cancer. Am J Epidemiol. 2007; 165(5):524-9.

\begin{tabular}{|c|c|}
\hline 口ytipa & $\begin{array}{l}\text { ARTICLE ON THE SITE } \\
\text { TRANSPLANTOLOGY.ORG }\end{array}$ \\
\hline
\end{tabular}

The authors declared no potential conflicts of interest with respect to the research, authorship, and/or publication of this article. 